\section{Challenges and perspectives for the promotion of adequate and healthy food in Brazil}

\author{
Desafios e perspectivas para a promoção da \\ alimentação adequada e saudável no Brasil
}

\author{
Desafíos y perspectivas para la promoción de una \\ alimentación adecuada y saludable en Brasil
}

1 Instituto de Nutrição, Universidade do Estado do Rio de Janeiro, Rio de Janeiro, Brasil.

Correspondence I. R. R. Castro Instituto de Nutrição Universidade do Estado do Rio de Janeiro.

Rua São Francisco Xavier 524,12 o andar, bloco D, sala 12.01, Rio de Janeiro, $R J$ 20550-013, Brasil. inesrrc@uol.com.br
Healthy foods are becoming more and more important in the agenda of public policies; today, their promotion is included in a number of national policies and programs. On the other hand, the eating habits of Brazilians are far from what would be desirable over the different stages of life course and in all social and economic strata, and have worsened in the last decades. In addition, the increase of obesity and obesity- and eating-related non-communicable chronic diseases, such as diabetes and high blood pressure are quite significant. In this scenario, one should ask how to move forward in the development of effective public policies for the promotion of adequate and healthy foods in the country?

To respond to this question, one should expand the analysis on eating to the contemporary context. For this purpose, we consider that there are five dimensions in relation to nourishment: human rights, biological (nutritional and sanitary aspects), sociocultural (system of values, relations of individuals and groups with food), economic (working relations established within the scope of the food systems, price of food), and environmental (forms of food production, commercialization, and use) 1 . This idea is reflected in the definition of what is adequate and healthy food made by the National Council on Food and Nutrition Security: "the fulfillment of a basic human right, with assurance of permanent and
Inês Rugani Ribeiro de Castro ${ }^{1}$

regular access, in a socially just form, to a practice of eating that is adequate to the biological and social aspects of the individuals, in accordance with the life cycle and the special nutritional needs, based on local products. It should comply with the principles of variety, balance, moderation, pleasure (flavor), with the dimensions of gender and ethnicity, and with the forms of production that are environmentally sustainable, free of physical, chemical and biological contaminants, and of genetically modified organisms" 2 . Thus, an effective response to the current food issue must include public policies that integrate health promotion, environmental sustainability, commitment with the assurance of rights and social justice.

Within this perspective, the knowledge of the characteristics and operating dynamics of the agrifood systems is fundamental, including the Brazilian one 1 . Some of them are highlighted here: (a) they are based on premises that are no longer applicable: stable climate, abundant water, cheap energy; (b) their products are food with non-nutritional components, such as agrotoxics, antibiotics, preservers and flavor enhancers, that have hazardous effects on health; (c) they degrade sustainable ecosystems due to their methods of food production, storage, transportation, and commercialization; (d) they replicate and deepen social inequalities in the access to land, water, energy and income; (e) despite 
presenting successive crop-harvesting records, they are inefficient in food production, transportation, storage, distribution, and domestic handling, generating waste and increase in the final price of the products; (f) they are marked by the concentration of the food-chain stages in big transnational corporations, such as the inputs and the seeds ones, the food industry, and the mega retail organizations; (g) by means of different mechanisms (economic, technological, and advertisement marketing), they promote the shift from natural and minimally processed foods to ready-for-consumption, ultraprocessed foods (PPCUP) 3, whose attributes are, among others: unbalanced nutritional composition (high levels of fat and/or sugar and or salt, low levels of fibers, high energetic density), hyperpalatability, and long duration, leading to the deterioration of traditional food crops and the decrease of food diversity. Counter-hegemonic movements are being organized to promote agroecology, and more sustainable production and commercialization processes, but they still are not powerful enough to cause a structural change in the agrifood systems that exist today.

The understanding that the food systems determine our choices is fundamental to understand that individual decisions, even though necessary, are not enough to ensure healthy and sustainable food practices by the population as a whole. Effectiveness will only be achieved by actions that combine measures targeted to people (educational activities, support activities) and measures targeted to the environment people live in. It is to be stressed that I understand environment in a perspective that goes beyond the one of "constructed environment", in accordance to the conceptual model about environment proposed by Swinburn et al. ${ }^{4}$. Its theoretical framework proposes two dimensions (micro and macro), and four types of environment (physical, economic, political, and sociocultural). Based on this referential, it is understood that, in order to be effective, healthy food promotion actions should combine measures that encompass the different dimensions and types of environment previously presented.

With that in mind, I believe the challenges and perspectives for the promotion of healthy food can be organized in two major axes. The first has, as a starting point, the understanding that eating is a social practice, this means, it is more than a behavior or an action of intaking food and other edible products that contribute for the prevention or occurrence of a set of diseases. This axis relates to giving new meaning to food, cooking, eating and commensality (eating and drinking together), rescuing its deep exis- tential sense and expanding the awareness of its political dimension.

There has been an expansion and diversification of initiatives to bring food back as one of the structuring axes of the collective identity (culture), and valuing consumption (including food consumption) as a political action, being considered here as the perception and use of consumption practices and choices (by individuals and collectively), as a way to participate in public sphere. The awareness of the political dimension of food is expressed, for instance, in the selection of what to eat and what not to eat, according not only to taste, tradition, or care with the health of an individual, but also considering its environmental, social and economic implications.

In this perspective, a basic aspect is raising awareness that healthy food practices (which include selection of food, ways to prepare meals and its sharing) are counterhegemonic in our society, and, therefore, require constant heed and dedication so that they are kept and cultivated. In this context, the valuing of the day-by-day cooking is becoming central in food and nutrition educational actions as an emancipatory (because it promotes autonomy), and self-care practice.

Within the scope of food and nutrition educational actions, a fundamental concern is the adoption of a food classification according to their grade of processing ${ }^{3}$ rather than to the nutrients they contain, which serves as reference on which the food pyramid is based, a symbol broadly used over the past few years in a number of countries, including Brazil, in educational activities that promote healthy food. The new Dietary Guidelines for the Brazilian Population, which was presented for public consultation early this year and was released on November 2014, uses this new approach. Classification systems that focus on the industrial processing of food provide precious elements for educational practices that meet the challenge of giving new meaning to food in our time.

The second axis of challenges and perspectives starts with the understanding that the necessary structural changes in the Brazilian agrifood system will not take place with individual changes or spontaneous initiatives of the production sector. This axis relates to the development of public policies that encourage and make the healthy choices easier, and that protect individuals and populations from factors and situations that lead to unhealthy choices. It also relates to the consolidation of public policies that respond, at the same time, to different problems of the food and nutrition agenda. A fundamental aspect for that is to improve regulatory actions that target different elements of the food system, 
such as, for instance, regulation of food advertisement, publicity (in the media, in specific environments), and labeling; regulation of school cafeterias; taxation or provision of subsidies to specific foods; regulation of the composition of ultraprocessed products; setting the direction of social programs, so that they expand their coverage and ensure mechanisms to promote a virtuous cycle in the food system (as the Program of Food Acquisition, and the National School Feeding Program); the revision of the sanitary code, to make it more inclusive to small producers (of which the Brazil Health Surveillance Agency's $R D C n .49 / 2013$ is an example). Even though there are important accomplishments in regards to this agenda in our country, the role of the public sector is still incipient, and faces strong and system- atic political resistance by the private sector to regulatory measures. For this agenda to advance significantly, it is instrumental to consolidate and to expand advocacy initiatives that already exist in our country, and to develop and strengthen mechanisms that regulate public-private relations in food and nutrition.

Advances in the promotion of healthy food in Brazil implies, therefore, the engagement and articulation of sectors and players from different areas, such as health, food and nutritional safety, environmental movements, countryside social movements, among others, that play a leading role in fostering structural changes in the consumption pattern and development model currently existing in our country.
1. Castro IRR, Castro LMC, Gugelmim SA. Ações educativas, programas e políticas envolvidos nas mudanças alimentares. In: Diez-Garcia RW, Cervato-Mancuso AM, organizadores. Mudanças alimentares e educação nutricional. Rio de Janeiro: Editora Guanabara Koogan; 2011. p. 18-34.

2. Conselho Nacional de Segurança Alimentar e Nutricional. III Conferência Nacional de Segurança Alimentar e Nutricional - por um desenvolvimento sustentável com soberania e segurança alimentar e nutricional. Relatório final. Fortaleza: Conselho Nacional de Segurança Alimentar e Nutricional; 2007.
3. Monteiro CA, Levy RB, Claro RM, Castro IRR, Cannon G. A new classification of foods based on the extent and purpose of their processing. Cad Saúde Pública 2010; 26:2039-49.

4. Swinburn B, Egger G, Raza F. Dissecting obesogenic environments: the development and application of a framework for identifying and prioritizing environmental interventions for obesity. Prev Med 1999; 29:563-70.

Submitted on 15/Sep/2014

Approved on 24/Sep/2014 